\title{
Macroeconomic Determinants of Stock Market Development in Ghana
}

\author{
Alexander Owiredu \\ Accounting and Finance Department, Pentecost University College, Ghana \\ E-mail: owiredualex@yahoo.com \\ Moses Oppong \\ Accounting and Finance Department, Pentecost University College, Ghana \\ E-mail: moppong@pentvars.edu.gh
}

\author{
Sandra A Asomaning \\ Pentecost University College, Ghana \\ E-mail: sandilom@gmail.com
}

Received: June 5, 2016

Accepted: June 13, 2016

Published: August 2, 2016

doi:10.5296/ifb.v3i2.9555

URL: http://dx.doi.org/10.5296/ifb.v3i2.9555

\begin{abstract}
Financial systems have been found to have a positive influence on the economic development of most countries. The stock market, which is also a component of the financial system is said to play an integral role in economic growth. This paper examines the macroeconomic determinants of stock market development in Ghana for the period 1992 to 2012 using annual secondary data from Bank of Ghana Quarterly Economic Bulletins, Ghana Statistical Service, Ghana Stock Exchange Market Statistics, the World Bank and IMF’s International Financial Statistics. The macroeconomic indicators such as the real income (GDP per capita income), domestic saving, stock market liquidity, financial intermediary growth, macroeconomic stability (inflation) and private capital flows with stock market capitalization used as a proxy for the study were collected and used for the analysis. These variables were examined to establish a relationship with stock market developments based on a linear regression model.

The regression analysis found stock market liquidity to be statistically significant to stock market developments as opposed to the other determinants (such as macroeconomic stability
\end{abstract}




\section{Macrothink}

International Finance and Banking

ISSN 2374-2089

2016, Vol. 3, No. 2

(inflation) real income and domestic savings and private capital flows) which were found to be non-significant. This result suggests that macroeconomic stability (inflation), real income, domestic savings and private capital flows proved not to have any significant impact on stock market development, since their regression coefficients were not statically significant at the $5 \%$ level of significance.

Keywords: Macroeconomic determinants, Stock market, Economic growth, Economic development, Financial intermediaries, Ghana 


\section{Introduction}

The relationship between stock market development and macroeconomic variables has been dealt with at both theoretical and empirical levels by a number of researchers such as McKinnon (1973), Shaw (1973) and Mun et al. (2008). Mun et al. (2008) observed that huge falls in stock prices are signs of future recession and the rise in stock prices can point to future economic growth. Other studies such as Demirguc-Kunt \& Levine (1996), Singh (1997), Levine \& Zervos (1998) and Osei (2005) have all revealed a positive relationship between stock market and economic growth. Levine \& Zervos (1998) also concluded with other authors that stock market development plays a significant role in determining future economic growth. They further added that stock markets have a robust impact on the performance of financial institutions; a position supported by Aduda et al. (2012). Indeed the importance of the relationship cannot be underestimated in both emerging and developing economies.

The proponents of stock markets have emphasized the importance of having a developed stock market in enhancing the efficiency of investment and thereby economic growth and development of a nation. Alile (1984) (as cited in Abrokwa et al. (2013)) posited that the use of the stock market as a regular device for mobilizing and allocating savings for various uses is beneficial to the growth and effectiveness of the economy. Senbet \& Otchere (2008) as cited in Osamwonyi \& Kasimu (2013) also mentioned that stock market evolutions and economic performance correlate to each other and their main mechanism is liquidity provision of the market. This makes a study in the stock market, which is a component of the financial system a major concern not only to researchers but also policymakers of every country.

Stock market development is a multi-dimensional concept. It is usually measured by stock market size, liquidity, volatility, concentration, integration with global capital markets, and the legal rule (regulation and supervision) in the market Garcia \& Liu (1999). Again, given the role played by financial systems in the development of the economy, most recent studies are directed towards establishing the linkages between stock markets and economic development.

In spite of the benefits stock market development brings to economic growth of both developing and emerging market literature indicates that only a few studies have been dealing with this issue in Ghana. It is in this regard that the paper studies the macroeconomic determinants of stock market development in Ghana. We do this by identifying the key macroeconomic determinants of stock market development in Ghana and establish the relationship between financial intermediary development and stock market development.

\section{Literature Review}

\subsection{Determinants of Stock Market Development}

The determinants of stock market development have drawn the attention of many governments, policy-makers, market regulators and scholars in recent times. Garcia \& Liu (1999) studied the macroeconomic determinants of stock market development during the 
period 1980 to 1995 using pooled data from 15 industrial and developing countries and found that real income, saving rate, inflation, financial intermediary development and stock market liquidity play a significant role in the development of stock markets. They observed that macroeconomic volatility does not prove to be significant and that stock market development and financial intermediaries' development are complements and not substitutes, A stock market, which is well-developed is supported by a mixture of factors such as sound macroeconomic/fiscal policies, institutional development, suitable legal and regulatory frameworks and availability of professional financial intermediaries such as investment banks or underwrites (Popiel, 1991; Paddy, 1992).

Quartey \& Gaddah (2007) looked at the long run determinants of stock market development in Ghana. The paper found that gross domestic savings, real income, domestic credit to the private sector, and exchange rate predicted the long run development of the GSE. However, Treasury bill rates had negative impact on the long run development of the GSE. Also, inflation did not prove to be a significant factor in predicting the long run development of the stock market.

Ayunku \& Etale (2014) examined the determinants of stock market development for the period 1977-2010, using ex-post facto research design and the utilization of Johansen Co-integration and Error Correction Model (ECM) approach. The empirical result indicates that market capitalization, credit to private sector and exchange rates are all important determinants of stock market development in both the long run and short run in Nigeria.

Finally, Kemboi \& Tarus (2012) investigated the macroeconomic factors that cause stock market development in Kenya for the period between 2000 and 2009, using quarterly secondary data collected from Nairobi Stock Exchange, Capital Markets Authority and Central Bank of Kenya. The ECM model was employed to estimate the link between macroeconomic variables and stock market development. The results confirmed that macroeconomic variables such as income level, banking sector development, and stock market liquidity are significant determinants of the development of the Nairobi Stock market. In addition, the findings showed that macroeconomic stability (measured by inflation) is not a significant forecaster of the development of the securities market.

\subsection{The Impact of Stock Market on Ghana's Economic Growth}

Numerous empirical tests including Garcia \& Liu (1999) have shown that financial variables have important impacts on economic growth using data from 44 industrial and developing countries from 1976 to 1993, Demirguc-Kunt \& Levine (1996a) concluded that stock market development goes hand-in-hand with financial intermediary development.

Acquah-Sam \& Salami (2014) concluded that capital market development has a positive and significant effect on long run economic growth in Ghana. Other studies on the Ghana Stock Exchange (GSE) by Osei (1998), Osei (2005) and Yartey (2006) asserted to the same findings. Osei (1998) examined the institutional factors that affect the development of GSE and the factors included legal and regulatory framework, transparency of transactions, information disclosure requirements and barrier to entry and exit. He went ahead to conduct 
efficiency tests on daily and weekly returns for the GSE before and after the listing of the Ashanti Goldfield Corporation (AGC) for the period 1993-1995. Their results established that the institutional factors specifically legal and regulatory frameworks strongly guarantee the protection and security of investors.

Osei (2005) employed a VAR technique developed by Sims (1972). The study centered on Granger's (1996) definition of causality to examine the relationship between stock market development and economic growth on a quarterly data for the period 1991 to 2003. He used quarterly data on nominal market capitalization and market capitalization ratio as the standard of stock market development and real GDP as a proxy for economic growth. The outcome of Granger-causality test shows that stock market development causes economic growth in Ghana.

Yartey (2006) also examined the financing practices of all non-financial listed companies based on their financial position between 1995 and 2005. He stated that the average listed Ghanaian companies are financed through the total assets from internal sources which is about $12 \%$, financing through external debt is about $48 \%$ whiles financing through new issues of equity is about $41 \%$. He noted that the stock market is the best source of long-term finance for Ghanaian listed firms and concluded that the stock market played an important role in financing the growth of large corporations in Ghana.

\section{Methodology}

\subsection{Variables for the Studt}

\section{Dependent Variable: Stock Market Development}

The stock market development is used as the dependent variable for this study. Stock market capitalization is determined by the total market value of all listed shares divided by GDP. The principle behind this assumption is that the total market size is definitely correlated with control to mobilize funds and diversify risk on an economy-wide base.

\section{Independent Variable: Income Level}

The size of the stock market can be attributed to real income. This is so, because according to the demand driven hypotheses an increase in income will create new demand for financial services. Garcia \& Liu, (1999) among a sample of Latin America and Asian countries found that income level have positive effect on stock market development. When income increases, its recurrent factor should influence the stock market size and price index. Moreover, an increase or a higher income improves living standards, creating wealth, encourages saving thereby enabling businesses operating in a better environment. This brings positive impact on the stock market size. The log of GDP per capita in US dollars is applied to the value of the income level. By the demand driven hypothesis, the elaboration of an economy will generate fresh demand for fiscal services (Yartey, 2008).

\subsection{Saving and Investment}

As stock markets are like financial intermediaries, intermediate saving is invested in projects 
or for business expansion. Normally, the quantity of capital flows through the stock market depends upon the extent of the saving (Garcia \& Liu, 1999). Therefore, savings and investments are expected to be the significant determinants of stock market development. The gross domestic saving as a percentage of GDP and gross domestic investment as a share of GDP are used.

\subsection{Stock Market Liquidity}

Liquidity according to Levine \& Zervos (1998) is defined as the ease and speed at which economic agents buy and sell securities in the stock market. According to Garcia \& Liu (1999), long-run commitments of capital are always needed for high-return projects due to high default and liquidity risks. Investors are usually reluctant to take such risks. Contrary to that, Levine (1991) found that, in the liquid stock markets, investors are given the opportunity to swiftly adapt portfolios, which are inexpensive and this facilitates long-term investments which are more profitable because of it less risks. In support of positive relationship between stock market liquidity and stock market development, Yartey (2008) argues that liquid markets affords investors access to their savings, and thus boost their confidence in stock market investment. Therefore, liquid markets help to improve the allocation of capital and enhance prospects for long term development. This encourages long term investment for more profitable tasks. The more liquid the stock market, the greater chances of conducting higher quantity of saving through the stock marketplace. Stock market liquidity is measured by using value traded as a percent of GDP. This ratio measures the value of equity transactions relative to the size of the economic system.

\subsection{Macroeconomic Stability}

Macroeconomic stability is also a significant factor for the stock market development. With a higher macroeconomic stability, it is expected that more firms and investors can take part in the stock market. A corporate profitability can be influenced by changes in monetary, fiscal and exchange rate policies. Therefore, we assumed that countries which have a stable macroeconomic environment should experience stronger developments in their stock markets. In line with the literature (Garcia \& Liu, 1999), the effect of macroeconomic stability on market capitalization is measured by the real interest rate and current inflation.

\subsection{Private Capital Flows}

For the intent of this subject area, capital flows were measured by using Foreign Direct Investment (FDI) as a share of GDP. According to Garcia \& Liu (1999), the last few decades have seen the emergence of foreign investors as the main partakers in stock market development. In 1982, Errunza said, the long term effect of foreign capital inflows on stock market development is more liberal than aids from initial flows and has increased investors partaking.

Foreign investment is controlled by an institutional and regulatory reforms, adequate disclosure and listing requirements and fair trading practices. In a study conducted in 1999 by Garcia and Liu, it was stated that other things being equal, a full disclosure of information and operational competences must ensure more trust in the local market. This can expand the 
investor base and contributions which are expected to increase and subsequently contribute to more capital flows.

\subsection{Data and Data Source}

The data for the study was collected from Bank of Ghana Quarterly Economic Bulletins; Ghana Statistical Service website, Ghana Stock Exchange Market Statistics website, the World Bank and IMF's International Financial Statistics website. The data set spans a period of twenty years (1992-2012) and was collected on different macroeconomic indicators: real income, inflation, domestic savings, stock market liquidity, financial intermediary growth, macroeconomic stability and private capital flows.

\section{Model Specification and Operational Definition of Variables}

The regression model used to determine the influence of each macroeconomic variable in the development of stock markets in Ghana is defined as follows:

$$
S M D_{t}=\beta_{0}+\beta_{1} I L_{t}+\beta_{2} F I D_{t}+\beta_{3} S I_{t}+\beta_{4} S M L_{t}+\beta_{5} M S_{t}+\beta_{6} P C_{t}+\varepsilon
$$

Where:

\begin{tabular}{|l|l|l|}
\hline Variable & Description & Measurement \\
\hline SMD & Stock market development & MC/GDP \\
\hline IL & Real income level & RI/GDP \\
\hline FID & Financial intermediary development & FID/GDP \\
\hline SI & Savings rate and investment & DSI/GDP \\
\hline SML & Stock market liquidity & SML/GDP \\
\hline MS & Macroeconomic stability & MS/GDP \\
\hline PCF & Private capital flows & PCF/GDP \\
\hline
\end{tabular}

The coefficients $\boldsymbol{\beta}_{\mathbf{1}}, \boldsymbol{\beta}_{\mathbf{2}}, \boldsymbol{\beta}_{\mathbf{3}}, \boldsymbol{\beta} \mathbf{4}, \boldsymbol{\beta 5}$, and $\boldsymbol{\beta}_{\mathbf{6}}$ will represent the coefficients of the respective independent variables and indicate the type of relationship between each of the independent variables and the dependent variable. $\boldsymbol{\beta}_{\boldsymbol{0}}$ and $\boldsymbol{\varepsilon}$ on the other hand represent the constant and the error term respectively.

\subsection{Data analysis}

The techniques employed to analyze the data include descriptive statistic, the unit root Augmented Dickey-Fuller (ADF) test and the ordinary least squares (OLS) multiple linear regression model. Studies which employed a similar approach included the ones conducted by Aduda, Masila, \& Onsongo (2012), Garcia \& Liu (1999), Yartey (2008); and Lazaridis \& Trofornidis (2006) while researching on relationship among variables. Additionally, Pearson correlation coefficient was used to estimate the relationship between the dependent variable and the corresponding independent variables 


\section{Results and Discussion}

\subsection{Summary of Descriptive Statistics}

This section analyses the descriptive statistics of the SMD and the following macroeconomic variables: IL, FID, SI, SML, MS, and PC. It begins by examining whether the data is normally distributed.

Table 1 and Table 2 respectively present the descriptive summary of the data and normality tests.

From Table 1, all variables exhibit a positive mean returns. Stock market capitalization has a mean value of 14.36 percent, with a standard deviation of 8.28 percent. This suggests that over the past 20 years, the SMD of Ghana has grown by an average of 14.3 percent.

Table 1. Descriptive statistics

\begin{tabular}{|l|l|l|l|l|l|}
\hline & $\mathrm{N}$ & Minimum & Maximum & Mean & Std. Deviation \\
\hline Stock Market Capitalization & 21 & 1.31 & 34.33 & 14.3610 & 8.27806 \\
\hline Macroeconomic Stability & 21 & 8.73 & 59.46 & 20.6752 & 13.04599 \\
\hline Real Income & 21 & 5.58 & 7.41 & 6.3253 & 0.61254 \\
\hline Domestic Savings & 21 & 1.26 & 28.00 & 8.6852 & 6.64526 \\
\hline Stock Market Liquidity & 20 & 0.08 & 1.38 & 0.4365 & 0.30749 \\
\hline Private Capital Flows & 21 & 0.35 & 9.52 & 3.7438 & 2.98489 \\
\hline Financial Intermediary Development & 21 & 4.84 & 15.83 & 11.1881 & 4.06979 \\
\hline Valid N (listwise) & 20 & & & & \\
\hline
\end{tabular}

MC/GDP = Stock Market Capitalization to GDP

PCF/GDP = Private Capital Flows to GDP

MS/GDP = Macroeconomic Stability to GDP

RI/GDP = Real Income to GDP

FID/GDP = Financial Intermediary Development to GDP

SML/GDP= Stock Market Liquidity to GDP

DS/GDP = Domestic Savings to GDP

This was achieved by performing a more incisive quantitative analysis such as the correlation analysis and regression analysis.

Establishing the normality of the data gathered was also necessary in determining its contribution to the stock market, especially most financial data are non-normal (skewed). The non-normality of the financial data could be attributed to the presence of outliers in the dataset and data frequency. The normality test was conducted under the assumption (null hypothesis) of normality against the alternative hypothesis of non-normality. The 
Shapiro-Wilk's (1965) test of normality was used and indicators with probability values greater than $5 \%$ were deemed normal and vice versa.

Table 2. Tests of normality

\begin{tabular}{|l|l|l|l|}
\hline \multirow{2}{*}{} & \multicolumn{3}{|l|}{ Shapiro-Wilk } \\
\cline { 2 - 4 } & Statistic & Df & Sig. \\
\hline Stock Market Capitalisation & .918 & 20 & .090 \\
\hline Macroeconomic Stability & .818 & 20 & .002 \\
\hline Real Income & .848 & 20 & .005 \\
\hline Domestic Savings & .792 & 20 & .001 \\
\hline Stock Market Liquidity & .855 & 20 & .006 \\
\hline Private Capital Flows & .818 & 20 & .002 \\
\hline Financial Intermediary Development & .866 & 20 & .010 \\
\hline
\end{tabular}

The details of the tests are presented in table 2 above. From the table, only one indicator was found to be normally distributed namely stock market capitalization. Macroeconomic stability (inflation), real income, domestic savings, stock market liquidity, private capital flows and financial intermediary development on the other hand were found to be skewed (non-normal).

Another important assumption that was met prior to using the economic variables in the regression is stationarity of the variables (Wooldrige, 2006). The tests for unit roots are closely related to the investigation of stationarity (or non-stationarity) in a time series. Augmented Dickey Fuller (ADF) (1979) was employed to check the stationarity of the selected variables. The test is applied to both the original series and to the first differences. Table 3 present the results of the ADF unit root test at levels and difference. The results from the ADF test indicate that apart from Macroeconomic stability (inflation) and Stock Market Liquidity all other variables (real income, domestic savings, private capital flows and financial intermediary development) were non-stationary at levels. Since the other variables were non-stationary at levels, each of these variables were tested by differencing. From Table 3 , it can be inferred that after first difference, all variables become stationary. The variables are significant at $1 \%$ and $5 \%$ confidence level. This indicates that all the variables: Macroeconomic stability (inflation), real income, domestic savings, stock market liquidity, private capital flows and financial intermediary development are stationary. 
Table 3. Results of unit roots test

\begin{tabular}{|l|l|l|l|l|}
\hline Variables & Level & Prob* & First difference & Prob* \\
\hline Financial Intermediary Development & -0.524126 & 0.0360 & -1.269532 & $0.0000^{* *}$ \\
\hline Macroeconomic stability & -2.312737 & $0.0000^{* *}$ & - & - \\
\hline Private Capital Flows & -3.819020 & 0.0560 & -0.824366 & $0.0030^{* *}$ \\
\hline Real Income & -1.145855 & 0.2333 & -0.755114 & $0.0051^{* *}$ \\
\hline Domestic Savings & -0.422125 & 0.4065 & -1.396182 & $0.0001^{* *}$ \\
\hline Stock Market Capitalisation & -0.601242 & $0.0098^{* *}$ & - & - \\
\hline Stock Market Liquidity & -1.275789 & $0.0005^{* *}$ & - & - \\
\hline
\end{tabular}

Note. ${ }^{* *}$ and ${ }^{*}$ Indicates that variables are stationary at $1 \%$ \& $5 \%$ significance level respectively.

\subsection{Pearson Correlation Results}

In establishing which indicators contribute to the stock market development in Ghana, the Pearson correlation coefficient was used. Pearson correlation is a statistical tool employed to assess the relationship between variables. The correlation matrix is an important indicator that tests the linear relationship, between the variables. In this study, the correlation coefficient test was used to test the relationship between stock market development and its determinants. Additionally, it helps to establish the strength of the variables in the model, that is, which variable best explains the relationship between stock market development and its determinants.

The correlation matrix of the variables is presented in table 3. From the table, some of the variables are positively correlated with the dependent variable, stock market capitalization, while others were negatively correlated. Among the variables that were positively correlated included macroeconomic stability (inflation), domestic savings and stock market liquidity with Pearson correlation coefficients $0.401,0.078$ and 0.748 respectively. Real income and private capital flows were found to be negatively correlated with stock market capitalization with -0.310 and -0.236 as their Pearson correlation coefficients respectively. It is also observed that apart from stock market liquidity, which recorded a high rate of association between itself and stock market capitalization, the rest recorded low rates, particularly domestic savings and private capital flows and therefore seemed not to influence stock market capitalization. 


\section{MlMacrothink}

Table 4. Pearson correlation coefficients

\begin{tabular}{|c|c|c|c|c|c|c|c|}
\hline & & $\begin{array}{l}\text { Stock Market } \\
\text { Development }\end{array}$ & $\begin{array}{l}\text { Macroeconomic } \\
\text { Stability }\end{array}$ & \begin{tabular}{|l} 
Real \\
Income
\end{tabular} & $\begin{array}{l}\text { Domestic } \\
\text { Savings }\end{array}$ & $\begin{array}{l}\text { Stock Market } \\
\text { Liquidity }\end{array}$ & $\begin{array}{l}\text { Private Capital } \\
\text { Flows }\end{array}$ \\
\hline \multirow{2}{*}{$\begin{array}{l}\text { Stock Market } \\
\text { Development }\end{array}$} & Pearson Correlation & 1 & .401 & -.310 & .078 & $.748 * *$ & -.236 \\
\hline & Sig. (2-tailed) & & .072 & .172 & .736 & .000 & .303 \\
\hline \multirow{2}{*}{$\begin{array}{l}\text { Macroeconomic } \\
\text { Stability } \\
\end{array}$} & Pearson Correlation & .401 & 1 & $-.498 *$ & .004 & -.032 & -.364 \\
\hline & Sig. (2-tailed) & .072 & & .022 & .988 & .893 & .105 \\
\hline \multirow{2}{*}{ Real Income } & Pearson Correlation & -.310 & $-.498^{*}$ & 1 & .426 & -.222 & $.851 * *$ \\
\hline & Sig. (2-tailed) & .172 & .022 & & .054 & .347 & .000 \\
\hline \multirow{2}{*}{$\begin{array}{l}\text { Domestic } \\
\text { Savings }\end{array}$} & Pearson Correlation & .078 & .004 & .426 & 1 & -.115 & .399 \\
\hline & Sig. (2-tailed) & .736 & .988 & .054 & & .628 & .073 \\
\hline \multirow{2}{*}{$\begin{array}{l}\text { Stock Market } \\
\text { Liquidity }\end{array}$} & Pearson Correlation & $.748^{* *}$ & -.032 & -.222 & -.115 & 1 & -.138 \\
\hline & Sig. (2-tailed) & .000 & .893 & .347 & .628 & & .561 \\
\hline \multirow{2}{*}{$\begin{array}{l}\text { Private Capital } \\
\text { Flows }\end{array}$} & Pearson Correlation & -.236 & -.364 & $.851 * *$ & .399 & -.138 & 1 \\
\hline & Sig. (2-tailed) & .303 & .105 & .000 & .073 & .561 & \\
\hline
\end{tabular}

Note. ${ }^{* *}$. Correlation is significant at the 0.01 level (2-tailed). *. Correlation is significant at the 0.05 level (2-tailed).

Table 4 shows that only stock market liquidity has a p-value (0.000) which is less than $5 \%$ with the rest of the variables recording p-values greater than $5 \%$. It can therefore be concluded that there is a statistically significant correlation between stock market liquidity and stock market development. This means that, increases or decreases in one of the two variables will significantly relate to increases or decreases in the other variable.

\subsection{Regression Analysis Results}

In view of the above, regression analysis was conducted to be able to establish the relationships and effects of macroeconomic stability (inflation), income level, domestic savings, stock market liquidity and private capital flows. This section presents the results of the regression analysis.

Table 5 shows the model summary and overall fit statistics of the multivariate linear regression (OLS) conducted, the test of linearity of the relationship between the variables.

It is observed that the adjusted $\mathrm{R}^{2}$ of the model is 0.5422 with the $\mathrm{R}^{2}=0.7038$. This suffices to say that the linear regression explains $70.4 \%$ of the variance in the data and suggests a good fit of the regression equation.

Further, the test of linearity of the relationship between the variables was verified and this has been presented in table 5 . The F-test of the linear regression model is based on the null hypothesis that there is no linear relationship between the variables under study. The results showed that the F-test is highly significant at the $5 \%$ confidence level since the Prob $>$ F value of $.0170<0.05$. Thus, it can be said that there is a linear relationship between the variables in the model. 
Table 5. Summary of regression model summary: dependent variable stock market development

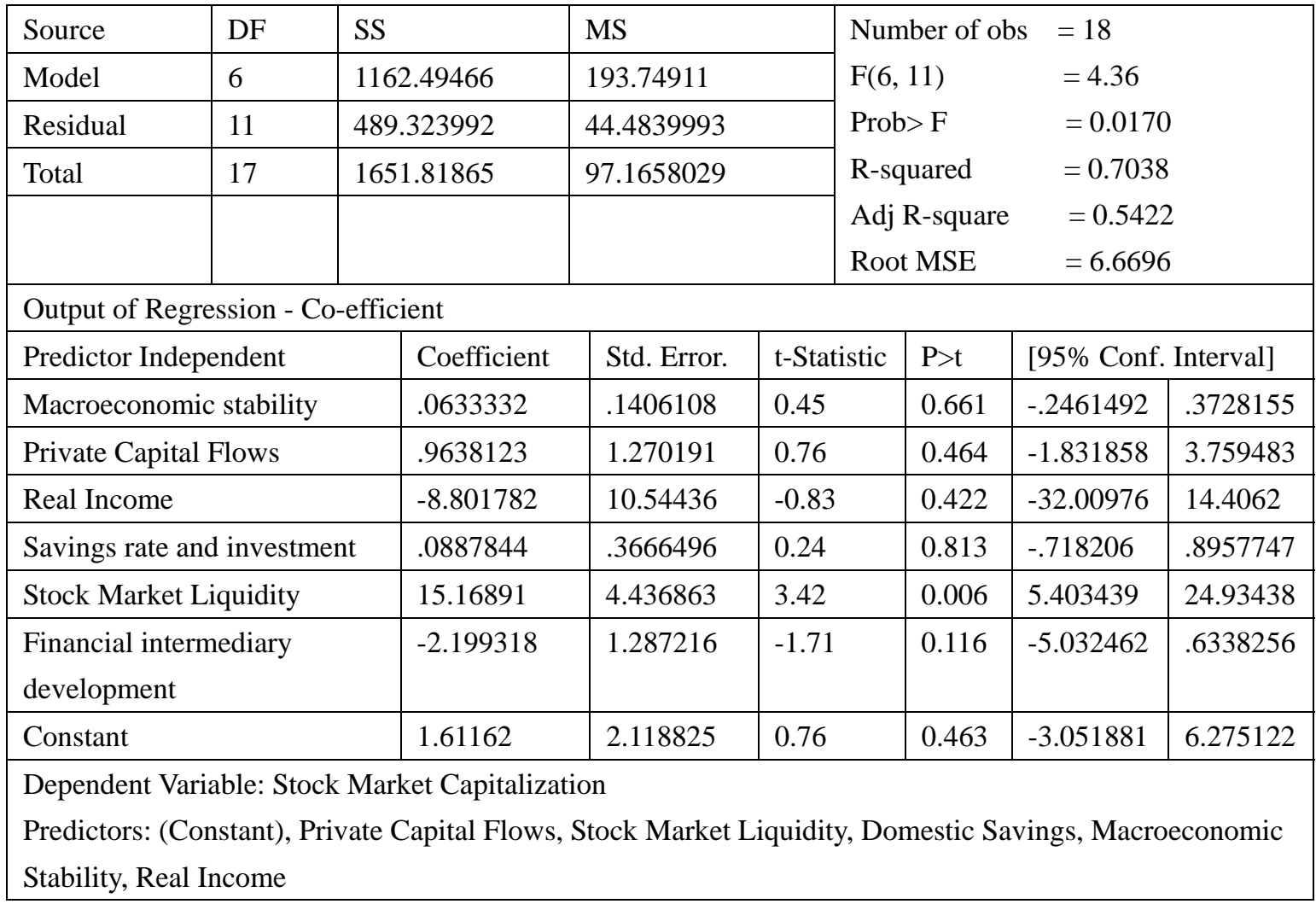

$$
\begin{gathered}
S M D_{t}=1.61162-8.80178 I L+0887844 S I+15.16891 S M L-2.199318 F I D+.0633332 M S \\
+.9638123 P C+\varepsilon
\end{gathered}
$$

Where: SMD-Stock Market Development; SML-Stock market liquidity; MS-Macroeconomic stability The regression results displayed in table 5 shows that only one out of the six variables studied were found to be significant at the $5 \%$ level of significance. This means that only stock market liquidity affect the stock market development in Ghana. The variable macroeconomic stability (inflation) real income, domestic savings and private capital flows on the other hand, proved not to have any significant impact on stock market development, since their regression coefficients were not statically significant at the $5 \%$ confidence level.

This further suffices that an increase in stock market liquidity by one (1) will cause stock market development to increase by $15.17 \%$ and vice versa.

The results of this study unlike that of Aduda et al. (2012) show that among the variables considered in the study, only stock market liquidity was found to be significant. The results however produced no significant relationship between stock market development and the rest of the indicators-macroeconomic stability (inflation), real income, domestic savings and private capital flows. Inferring from the results, it can be said that stock market liquidity is the main determinant of stock market development in Ghana. 
Correlation between SMC and FID

\begin{tabular}{|l|l|l|l|}
\hline \multicolumn{2}{|l|}{ Correlations } & $\begin{array}{l}\text { Stock Market } \\
\text { Capitalizations }\end{array}$ & $\begin{array}{l}\text { Financial Intermediary } \\
\text { Development }\end{array}$ \\
\hline \multirow{2}{*}{ Stock Market Capitalisation } & Pearson Correlation & 1 & -.256 \\
\cline { 2 - 4 } & Sig. (2-tailed) & & .263 \\
\hline \multirow{2}{*}{ Financial Intermediary Development } & Pearson Correlation & -.256 & 1 \\
\cline { 2 - 4 } & Sig. (2-tailed) & .263 & \\
\hline
\end{tabular}

The above table presents the correlation between stock market development and financial intermediary development (measured by only domestic credit to the private sector divided by GDP). The Pearson correlation coefficient recorded between stock market development and financial intermediary development is -0.256 . This means that a weak association exists between stock market development and financial intermediary development in the opposite direction. Thus, an increase in domestic credit to the private sector divided by GDP by 1\% will result in a decrease in stock market development by 0.256 and vice versa. The correlation between the two was not significant since the P-value recorded, $0.263>0.05$. This was probably due to the fact that financial intermediary development was measured by only one indicator (domestic credit to the private sector divided by GDP) instead of the usual two. This result is unusual compared with several other studies such as the one by Demirguc-Kunt \& Levine (1996) among others where financial intermediary development was found to be positively significant with stock market development. In contrast, Quaidoo (2011) shows that the banking sector development has a significant negative relationship with the stock market development suggesting that they are substitutes in financing corporate investments in Ghana.

\section{Conclusion and Recommendation}

\subsection{Macroeconomic Determinant of Stock Market Development in Ghana}

The study centered on six key macroeconomic indicators which determine the development of the Ghana stock market. These included that macroeconomic stability (inflation), private capital flows, stock market liquidity, domestic savings and real income. Stock market capitalization was used as a substitute for the stock market development.

Results show that stock market liquidity was found to contribute significantly to the stock market development in Ghana. Even though the rest of the indicators with the exception of Real Income and Financial intermediary development influence the growth of the stock market, however they were not found to be significantly related

The significance of the stock market liquidity confirmed other studies conducted by other researchers such as Aduda et al. (2012), Yartey (2008) and Garcia \& Liu (1995).

\subsection{Relationship between Financial Intermediary Development and Stock Market Development in Ghana}

Various studies have pointed to the fact that most stock market indicators, especially in states 
with well-developed stock markets are highly interrelated with the financial intermediary development. One of such studies was the ones conducted by Demirguc-Kunt \& Levine (1996).

The results produced by the study showed that within the study period, the performance of FID showed a non-significant negative association between FID and stock market development. Nonetheless, the association was not too strong as in the case in other studies.

This study tried to determine the key macroeconomic indicators of stock market growth in Ghana whilst at the same time attempting to make the relationship between financial intermediary development and stock market development. Among the indicators that were considered included real income, domestic savings, private capital flows, stock market liquidity and macroeconomic stability. Even though contribute were not significant. Again financial intermediary development was found to cause a negative non-important relationship with the stock market, thereby meaning that the stock market and financial intermediaries are substitutes rather than complementing.

The dependent variable, stock market capitalization was found not to have performed well within the study period. Whereas some of the indicators were going up steadily over the period, the stock market capitalization was performing other than. This likely affected the end product of the study.

\section{Recommendation}

The findings of this study are really keys to the economic development of Ghana. Investors and policy makers will also take clues from these findings. At the end of the study, the under listed recommendations were made:

- There is the urgent need for government to initiate appropriate policies that will facilitate the improvement of the other macroeconomic indicators that did not prove significant, as per this study such as domestic savings, private capital flows and real income to ensure that the stock market in an emerging economy like Ghana is improved significantly since it consequently affect the entire growth of the economy.

- Given the role played by financial intermediaries in stock market development, it is imperative for government to initiate policies to foster their growth and development.

- $\quad$ Stock market liquidity has a strong relationship with stock market development in Ghana. Improving stock market liquidity in Ghana therefore can be an alternative approach of promoting stock market development.

\section{References}

Abrokwa, E. A. et al. (2013). The impact of Ghana stock exchange on the growth of the capital market of Ghana.

Alile, H. (1996). Dismantling barrier of foreign capital inflows. The Business Times.

Alile, H. (1997). Government must divest. The Business Concord of Nigeria 2nd December. 
Asli, D. K., \& Levine, R. (1996). Stock Markets, Corporate Finance and Economic Growth: An Overview. The World Bank Economic Review, 10(2).

Bagehot. (1873). A description of money market with currency monopoly. Homewood ILRichard.

Boateng, S. (2010). The impact of foreign direct investment on Ghana's capital market. Martinus Nijhoff, 28(6), 498-501.

Campos, F., Filer, R. K., \& Hanousek, J. (1999). Do stock market promote economic growth? CERGE-EI Working Papers.

Cooper, R. D., \& Schindler, S. P. (2003). Business research methods (8th ed.). New York: McGraw-Hill/Irwin

El-Nader, H. M., \& Alraimony, A. D. (2013). The Macroeconomic determinants of stock market development in Jordan international. Journal of Economics and Finance, 5(6), 91-103. http://dx.doi.org/10.5539/ijef.v5n6p91

Gamolya, A. (2006). Stock market and economic growth in Ukraine.

Garcia, F. V., \& Liu, L. (1999). Macroeconomic determinants of stock market development. Journal of Applied Economics, 2(1), 29-59.

Kenny, C., \& Moss T. D. (1998). Stock market in Africa. Emerging Lions or White Elephants? World Development, 26, 29-43. http://dx.doi.org/10.1016/S0305-750X(98)00019-9

Kominek, Z. (2003). Stock markets and industry growth: An Eastern European perspective. Applied Economics, 36(10), 1025-1030. http://dx.doi.org/10.1080/0003684042000246731

Levine, R., \& Zervos, A. (1998). Stock markets, banks and economic growth. American Economic Review, 88(3), 537-558

Levine, R., \& Zervos, S. (1996). Stock market development and long- run growth. The World Bank Economic Review, 10(2). http://dx.doi.org/10.1093/wber/10.2.323

Nyong, M. O. (1997) Capital market development and long run economic growth: Theory, Evidence and Analysis. First Bank Review.

Osamwonyi, I. O. (2005). Capital market imperfections and community economic development in Nigeria. Being a paper presented at the Academy of Management Nigeria, on the 23rd of November, at Abuja.

Osamwonyi, I. O., \& Kasimu. (2013). Stock market and economic growth in Ghana, Kenya and Nigeria stock. International Journal of Financial Research, 4(2). http://dx.doi.org/10.5430/ijfr.v4n2p83

Osei, V. (2005). Does the Stock Market matter in Ghana? A Granger-Causality Analysis. Working Paper, Bank of Ghana.

Saunders, M., Lewis, P., \& Thornhill, A. (2007). Research methods for business students. 
Financial Times. Prentice Hall.

Sililo, M. (2010). Stock market development and economic growth: A Case for Zambia. Research Report Presented in Partial Fulfillment of the Requirements for the Degree of Masters of Business Administration at the University of Stellenbosch.

Yartey, C. A., \& Adjasi, C. K. (2007). Stock market development in Sub-Saharan Africa: critical issues and challenges. IMF Working Paper No. 07/209.23w23w.

\section{Copyright Disclaimer}

Copyright for this article is retained by the author(s), with first publication rights granted to the journal.

This is an open-access article distributed under the terms and conditions of the Creative Commons Attribution license (http://creativecommons.org/licenses/by/3.0/). 